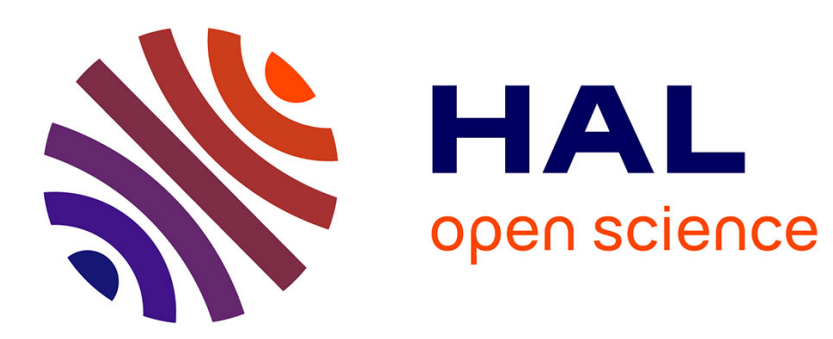

\title{
RichardsFoam2: A new version of RichardsFoam devoted to the modelling of the vadose zone Laurent Orgogozo
}

\section{To cite this version:}

Laurent Orgogozo. RichardsFoam2: A new version of RichardsFoam devoted to the modelling of the vadose zone. Computer Physics Communications, 2015, vol. 196, pp. 619-620. 10.1016/j.cpc.2015.07.009 . hal-01299854

\section{HAL Id: hal-01299854 \\ https://hal.science/hal-01299854}

Submitted on 8 Apr 2016

HAL is a multi-disciplinary open access archive for the deposit and dissemination of scientific research documents, whether they are published or not. The documents may come from teaching and research institutions in France or abroad, or from public or private research centers.
L'archive ouverte pluridisciplinaire HAL, est destinée au dépôt et à la diffusion de documents scientifiques de niveau recherche, publiés ou non, émanant des établissements d'enseignement et de recherche français ou étrangers, des laboratoires publics ou privés. 


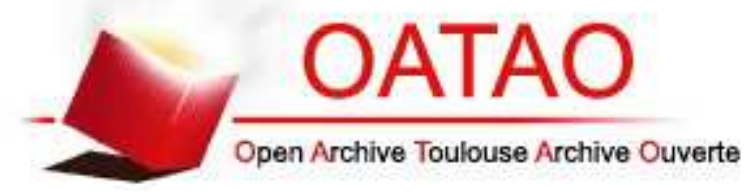

\section{Open Archive TOULOUSE Archive Ouverte (OATAO)}

OATAO is an open access repository that collects the work of Toulouse researchers and makes it freely available over the web where possible.

This is an author-deposited version published in : http://oatao.univ-toulouse.fr/ Eprints ID : 15678

To link to this article : DOI:10.1016/j.cpc.2015.07.009

URL : http://dx.doi.org/10.1016/j.cpc.2015.07.009

\section{To cite this version :}

Orgogozo, Laurent RichardsFoam2: A new version of

RichardsFoam devoted to the modelling of the vadose zone. (2015)

Computer Physics Communications, vol. 196. pp. 619-620. ISSN

0010-4655

Any correspondence concerning this service should be sent to the repository administrator: staff-oatao@ listes-diff.inp-toulouse.fr 


\section{RichardsFoam2: A new version of RichardsFoam devoted to the modelling of the vadose zone}

\section{Laurent Orgogozo}

GET (Géosciences Environnement Toulouse), Observatoire Midi-Pyrénées, Université Paul Sabatier, Université de Toulouse, 14 avenue Édouard Belin, 31400 Toulouse, France

Keywords:

Richards equation

OpenFOAM ${ }^{\circledR}$

Heterogeneous soils

Rain

Evapotranspiration

\section{A B S T R A C T}

RichardsFoam2 is an updated version of the OpenFOAM ${ }^{\circledR}$ solver RichardsFoam, presented in Orgogozo et al., Comput. Phys. Commun. 2014. The new features are the following:

(i) The direct handling of fully heterogeneous porous media, with all the van Genuchten parameters defined as spatially varying scalar fields.

(ii) The computation of the density of water flux at each face of the mesh cells, which allows the implementation of fixed water flux (e.g.: rain flux) boundary conditions.

(iii) The integration in the water flow resolution of the actual evapotranspiration within the root zone, computed on the basis of the potential evapotranspiration.

These new features allow to deal with the hydrology of real (i.e.: heterogeneous) soils in natural conditions, submitted to rain and evapotranspiration. Thus it considerably broadens the field of applicability of the OpenFOAM ${ }^{\circledR}$ solver for Richards equation.

The description of the elements contained in this release may be found in the readMe file. In RichardsFoam2_presentation.pdf, one will find a more detailed description of the new features offered by RichardsFoam2 (equations, descriptions of the proposed test cases, ...).

\section{New version program summary}

Program title: RichardsFoam2

Catalogue identifier: AEUF_v2_0

Program summary URL: http://cpc.cs.qub.ac.uk/summaries/AEUF_v2_0.html

Program obtainable from: CPC Program Library, Queen's University, Belfast, N. Ireland

Licensing provisions: Standard CPC licence, http://cpc.cs.qub.ac.uk/licence/licence.html

No. of lines in distributed program, including test data, etc.: 17321

No. of bytes in distributed program, including test data, etc.: 3353265

Distribution format: tar.gz

Programming language: $\mathrm{C}++$.

Computer: Any x86, tested only on 64-bit machines.

Operating system: Generic Linux.

Has the code been vectorized or parallelized?: The given test cases are run serially, however, it is designed to allow the use of parallel computation with several thousands of cores.

$R A M$ : For the given test cases, around 20 megabytes. But it can vary considerably along the considered problems.

Catalogue identifier of previous version: AEUF_v1_0

Journal reference of previous version: Comput. Phys. Comm. 185(2014)3358

Classification: 13.

External routines: OpenFOAM ${ }^{\circledR}$ (version 2.0.1 or later) with swak4foam (openfoamwiki.net/index.php/ Contrib/swak4Foam) 
Does the new version supersede the previous version?: Yes

Nature of problem: This software solves the non-linear three-dimensional transient Richards equation, which is a very popular model for water transfer in variably saturated porous media (e.g.: soils). It is designed to take advantage of the massively parallel computing performance of OpenFOAM ${ }^{\circledR}$. The goal is to be able to model natural hydrosystems on large temporal and spatial scales.

Solution method: A mixed implicit (FVM in the object oriented OpenFOAM ${ }^{\circledR}$ framework) and explicit (FVC in the object oriented OpenFOAM ${ }^{\circledR}$ framework) discretization of the equation with a backward time scheme is coupled with a linearization method (Picard algorithm). Due to the linearization loop the final solution of each time step tends towards a fully implicit solution. The implementation has been carried out with a concern for robustness and parallel efficiency.

Reasons for new version: New features were implemented.

Summary of revisions: This new version integrates a sink term in Richards equation in order to take into account evapotranspiration, and this new version also allows rain infiltration and heterogeneous soils to be dealt with easily.

Restrictions: The choice of the maximum and initial time steps must be made carefully in order to avoid stability problems. A careful convergence study of mesh cell size, linear solver precision and linearization method precision must be undertaken for each considered problem, depending on the precision required for the expected results, the spatial and temporal scales at stake, and so on. Finally, the solver in its current version only handles meshes with a constant cell volume (a crash will not necessarily occur with an irregular mesh but some problems may arise with the convergence criterion of the linearization method).

Running time: Highly variable, depending on the mesh size and the number and nature of cores involved. The test runs provided require less than 2 seconds on a 64 bit machine with Intel ${ }^{\circledR}$ CoreTMi7-2760QM CPU @ 2.40GHz x8 and 3.8 Gigabytes of RAM. 